Research Article

\title{
Increased Rate of Cesarean Section among Teenage Mothers Attending a Tertiary Teaching Hospital in Indonesia
}

\author{
Peningkatan Angka Seksio Sesarea pada Ibu Remaja yang Datang \\ ke Suatu Rumah Sakit Pendidikan di Indonesia
}

\author{
I Putu G Kayika, Teuku K I Utama \\ Department of Obstetrics and Gynecology \\ Faculty of Medicine Universitas Indonesia/ \\ Dr. Cipto Mangunkusumo Hospital \\ Jakarta
}

\begin{abstract}
Objective: To evaluate adverse obstetrical outcome in teenage pregnancy, and to investigate whether the social factor, demographic factor, and antenatal care is associated with the management of delivery in teenage pregnancy.

Methods: A cross-sectional study was conducted by evaluating medical records teenage mothers who went to Dr. Zainoel Abidin Hospital, Banda Aceh, Indonesia during the period of January 2010 to December 2015 .

Results: From 186 teenage pregnancies, 75 pregnancies was terminated by cesarean section procedures $(40.3 \%)$. The amount of antenatal care visit was significantly associated with teenage pregnancy (OR 4.14, CI95\% 1.86-9.21). The provider of antenatal care, maternal age classification, education, and insurance were not signifcantly associated with management of labour.

Conclusion: Teenage pregnancy is associated with higher cesarean section rate.

[Indones J Obstet Gynecol 2017; 5-3: 131-134]

Keywords: cesarean section, profile, teenage pregnancy
\end{abstract}

\begin{abstract}
Abstrak
Tujuan: Untuk mengetahui luaran Obstetrik buruk pada kehamilan remaja serta mengetahui apakah terdapat hubungan antara faktor sosiodemografik dan kunjungan antenatal dengan metode persalinan pada kehamilan remaja.

Metode: Analisa potong-lintang dilakukan pada persalinan dengan kehamilan remaja di Rumah Sakit Umum Daerah (RSUD) Dr. Zainoel Abidin, Banda Aceh, Indonesia, yang diambil dari rekam medis pasien pada bulan Januari 2010 sampai dengan Desember 2015.

Hasil: Dari 186 persalinan remaja, sebanyak 75 subjek atau 40,3\% menjalani seksio sesarea. Jumlah ANC berhubungan secara bermakna dengan jenis persalinan pada kehamilan remaja $(O R 4,14, I K$ $95 \%$ 1,86-9,21). Sedangkan usia ibu, penyedia jasa kunjungan antenatal, jenis asuransi, dan pendidikan terakhir tidak berhubungan secara bermakna dengan jenis persalinan.

Kesimpulan: Kehamilan remaja berhubungan dengan angka seksio sesarea yang lebih tinggi.

[Maj Obstet Ginekol Indones 2017; 5-3: 131-134]

Kata kunci: kehamilan remaja, profil, seksio sesarea
\end{abstract}

\section{INTRODUCTION}

Each year, 15 million children were born to teenage mothers aged 15-19 years. ${ }^{1}$ In developing countries, approximately 2.5 million births occur in women under the age of 16 . The number continues to increase both in developed ${ }^{3}$ and developing countries. ${ }^{2,4,5}$ This might be due to multifactorial conditions such as socioeconomic factors, disruption of family structure, and low education levels. ${ }^{4,6,7}$

Teenage pregnancy is considered as high-risk pregnancy since it may cause physicological problems $^{8}$ and poor fetomaternal outcomes ${ }^{9,10}$, both of which are not caused by biological problems but possibly due to poor health habits or high nutritional needs. ${ }^{11}$ Some studies suggested that maternal and fetal outcomes of teenage pregnancies were less favorable compared to adult pregnancies. ${ }^{10,12}$ It is previously reported that teenage mothers had higher cesarean section rate compared to adult mothers. ${ }^{13}$ In addition, adverse outcomes including preterm labor, premature rupture of membranes (PROM), gestational hypertension, preeclampsia, Apgar score of less than 7 minutes to 5, fetal growth restriction, and stillbirth, were found to be higher in women aged under 19 years compared to older women. However, Bukulmez et al found that the fetomaternal outcomes were similar among teenagers who got 
adequate prenatal care compared to adult mothers with the same sociodemographic backgrounds. ${ }^{14}$ Ukil et al found better pregnancy outcomes in adolescents who visited dedicated antenatal clinics compared to those who visited standard antenatal clinics. ${ }^{15}$

Increased rate of cesarean section has became one of the main concerns in the field of public health. High cesarean section may lead to high mortality and morbidity, with increased number of uterine rupture, placenta accreta and postpartum hemorrhage. ${ }^{16-18}$ Each year, 18.5 million cesarean sections were performed worldwide. The World Health Organization (WHO) recommends that the ideal number of cesarean section is $15 \%$. In 2008, WHO reported that the rate of cesarean section in Indonesia was $6.8 \%{ }^{19}$ Asia's global survey suggested that the cesarean section rate among 9 countries was $27.3 \%{ }^{20}$ The relative proportions of cesarean section rate compared to the amount of labor were used as indicators of the overall process of quality emergency services of the United Nations (UN). ${ }^{21}$

The high number of cesarean section on adolescent health should be a focus of attention, since it may lead to greater maternal and mortality rate. This study is aimed to investigate the association between teenage pregnancy and cesarean section rate.

\section{METHODS}

A cross-sectional analysis was conducted at Dr. Zainoel Abidin Hospital, Banda Aceh, Indonesia, during the period of January 2010 to December 2015. All statistical analyses were performed using SPSS. Normally distributed data were presented in the form of median (minimum-maximum), while non-normal data were presented in mean +/standard deviations. The Chi-Square test or the Fisher's exact test was used to analyze categorical variables. A p value of $<0.05$ was considered as statistically significant.

\section{RESULTS}

During January 2010 to December 2015 there were 186 deliveries in adolescents at Dr. Zainoel Abidin Hospital, Banda Aceh. A total of 40.3\% subjects underwent cesarean deliveries, whereas $59.7 \%$ underwent vaginal delivery. The median maternal age was 18.5 years.
The median gestational age was 38 weeks, with the smallest age at delivery was 34 weeks and the biggest was 42 weeks. The median birth weight was 2900 grams, with the lightest weight and heaviest weight were 1090 and 4200 grams, respectively (Table 1 ).

Table 1. Characteristics of the Subjects.

\begin{tabular}{lcc}
\hline \hline & Median (Min-Max) & N (\%) \\
\hline \multicolumn{3}{c}{ N=186 } \\
Age & 18.5 yo (12-19) \\
Age classification & \\
$12-14$ & $1(0.5 \%)$ \\
$15-17$ & $35(18.8 \%)$ \\
$18-19$ & $150(80.6 \%)$ \\
Gestational Age & \\
Birth weight & $38(34-42)$ & \\
Type of Insurance & & \\
Jamkesmas & & \\
Aceh health insurance & & $180(9.2 \%)$ \\
Methods of delivery & & \\
Caesarean section & & \\
Vaginal delivery & $111(59.8 \%)$ \\
\hline \hline
\end{tabular}

Table 2. The Proportion of Cesarean Section Indication in Adolescents.

\begin{tabular}{lc}
\hline \hline Failed labor induction & $\begin{array}{c}\text { N (\%) } \\
\mathbf{n = 7 5}\end{array}$ \\
PROM & $19(25.3 \%)$ \\
Malpresentation & $11(14.7 \%)$ \\
Preeclampsia & $10(13.3 \%)$ \\
Cephalopelvic disproportion & $8(10.6 \%)$ \\
Dystocia & $5(6.7 \%)$ \\
Fetal distress & $4(5.3 \%)$ \\
Eclampsia & $4(5.3 \%)$ \\
Distocia second phase & $3(4.0 \%)$ \\
Olygohidramnios & $3(4.0 \%)$ \\
Intrauterine fetal death & $2(2.7 \%)$ \\
Previous caesarean section & $2(1.1 \%)$ \\
Twin pregnancy & $1(1.3 \%)$ \\
Heart defect & $1(1.3 \%)$ \\
Macrosomia & $1(1.3 \%)$ \\
Postterm pregnancy & $1(1.3 \%)$ \\
\hline \hline
\end{tabular}


Table 3. Association between Antenatal Care Visits and Methods of Delivery.

\begin{tabular}{|c|c|c|c|c|c|c|c|c|}
\hline \multirow[t]{2}{*}{ Variables } & \multicolumn{2}{|c|}{$N(\%)$} & \multicolumn{3}{|c|}{ Unadjusted } & \multicolumn{3}{|c|}{ Adjusted } \\
\hline & $\begin{array}{l}\text { Vaginal delivery } \\
\quad(\mathrm{n}=111)\end{array}$ & $\begin{array}{c}\text { Caesarean } \\
\text { Section } \\
(\mathrm{n}=75)\end{array}$ & $\mathrm{p}$ & OR & IK95\% & $\mathrm{p}$ & OR & IK95\% \\
\hline \multicolumn{9}{|l|}{ Antenatal care visits } \\
\hline$\geq 4$ & $61(55 \%)$ & $20(26.7 \%)$ & $<0.001^{* a}$ & 3.335 & $1.78-6.32$ & $<0.001$ & 4.57 & $1.89-11.04$ \\
\hline$<4$ & $50(45 \%)$ & $55(73.3 \%)$ & & & & & & \\
\hline \multicolumn{9}{|l|}{ Provider } \\
\hline \multicolumn{9}{|l|}{ Midwife } \\
\hline General doctor & 97 (87.4\%) & $65(86.7 \%)$ & & & & & & \\
\hline Obstetrician- & $1(0.9 \%)$ & $1(1.3 \%)$ & $0.332^{\mathrm{b}}$ & & & & & \\
\hline gynecologist & $8(7.2 \%)$ & $2(2.7 \%)$ & & & & & & \\
\hline \multicolumn{9}{|l|}{ Age } \\
\hline $10-14$ & $0(0 \%)$ & $1(1.3 \%)$ & & & & & & \\
\hline $15-17$ & $25(22.5 \%)$ & $10(13.3 \%)$ & $0.147 \mathrm{~b}$ & & & & & \\
\hline 18-19 & $86(77.5 \%)$ & $64(85.3 \%)$ & & & & & & \\
\hline \multicolumn{9}{|l|}{ Education } \\
\hline Primary school & $0(0 \%)$ & $1(1.3 \%)$ & & & & & & \\
\hline Junior high school & $9(8.1 \%)$ & $3(4.0 \%)$ & $0.26^{b}$ & & & & & \\
\hline High school & $102(91.9 \%)$ & $71(94.7 \%)$ & & & & & & \\
\hline \multicolumn{9}{|l|}{ Insurance } \\
\hline \multicolumn{9}{|l|}{ Jamkesmas } \\
\hline Aceh health & $2(1.8 \%)$ & $4(5.3 \%)$ & & & & & & \\
\hline insurance & $109(98.2 \%)$ & $6(3.2 \%)$ & $0.22^{\mathrm{b}}$ & & & & & \\
\hline
\end{tabular}

${ }^{a}$ Using Chi-Square test ${ }^{b}$ Using Fisher's exact test

\section{DISCUSSION}

The incidence of cesarean section among adolescents in this study was $40.3 \%$. This number is similar to a previous study conducted in Brazil. Gama et al found a high number of cesarean section in a hospital in Brazil, which was amounted to $40 \%{ }^{22}$

To investigate the association between teen pregnancy and obstetric and neonatal outcomes, the quality of antenatal visits and socio-economic factors. The role of maternal characteristics on maternal outcome is still controversial. Socioeconomic factors such as low education, being a single parent, and inadequate prenatal visits, may increase the risk of poor obstetric outcomes. ${ }^{4,6,8}$ In addition, poor quality antenatal, nutritional status, and the lack of involvement of the husband, adolescents may have influenced the outcomes are worse in pregnancy. However, de Vinne suggested that socio-economic characte- ristics were not likely to affect fetomaternal outcome. ${ }^{23}$

This study used cross-sectional design as its study design, thereby the value of the association is not as strong as cohort studies. Another limitation of this study is the data were taken from secondary data from medical records. Further studies with prospective study designs are required.

\section{CONCLUSION}

Teenage pregnancy is associated with higher cesarean section rate. Frequency of appropriate antenatal visits are associated with methods of delivery among teenage mothers. Further studies regarding socio-economic factors that affect the quality of antenatal visits and fetomaternal outcomes in adolescent pregnancies need to be investigated. 


\section{REFERENCES}

1. UNICEF. Young people and Family Planning: Teenage Pregnancy. http://www.unicef.org/malaysia/Teenage_Pregnancies_-_Overview.pdf. 2015: 1-3.

2. Neal S, Matthews Z, Frost M, Fogstad H, Camacho AV, Laski L. Childbearing in adolescents aged 12-15 years in low resource countries: a neglected issue. New estimates from demographic and household surveys in 42 countries. Acta Obstet Gynecol Scand. 2012; 12;91(9): 1114-8.

3. Whitworth M, Cockerill R. Antenatal management of teenage pregnancy. Obstet Gynaecol Rep Med. 2010; 20(11): 323-8.

4. Ibrahim Isa A. Socio-demographic determinants of teenage pregnancy in the Niger Delta of Nigeria. OJOG. 2012; 02(03): 239-43.

5. Kulin HE. Adolescent pregnancy in Africa: A programmatic focus. Soc Sci Med. 1988; 26(7): 727-35.

6. Imamura M, Tucker J, Hannaford P, da Silva MO, Astin M, Wyness L, et al. Factors associated with teenage pregnancy in the European Union countries: a systematic review. Eur J Public Health. 2007; 14;17(6): 630-6.

7. Were M. Determinants of teenage pregnancies: The case of Busia District in Kenya. Econ Hum Biol. 2007; 5(2): 322-39.

8. Shaw M, Lawlor DA, Najman JM. Teenage children of teenage mothers: Psychological, behavioural and health outcomes from an Australian prospective longitudinal study. Soc Sci Med. 2006; 62(10): 2526-39.

9. Keskinoglu P, Bilgic N, Picakciefe M, Giray H, Karakus N, Gunay T. Perinatal Outcomes and Risk Factors of Turkish Adolescent Mothers. J Pediatr Adolesc. 2007; 20(1): 19-24.

10. Pergialiotis V, Vlachos DEG, Gkioka E, Tsotra K, Papantoniou $\mathrm{N}$, Vlachos GD. Teenage pregnancy antenatal and perinatal morbidity: Results from a tertiary centre in Greece. J Obstet Gynecol. 2014; 19: 1-5.

11. Zuckerman BS, Waller DK, Frank DA, Chase C, Hamburg B. Adolescent pregnancy: Biobehavioral determinants of outcome. J Pediatr. 1984; 105(6): 857-63.

12. Gupta N, Kiran U, Bhal K. Teenage pregnancies: Obstetric characteristics and outcome. Eur J Obstet Gynecol Reprod Biol. 2008; 137(2): 165-71.

13. Bacci A, Manhica GM, Machungo F, Bugalho A, Cuttini M. Outcome of teenage pregnancy in Maputo, Mozambique. Int J Gynecol Obstet. 1993; 40(1): 19-23.
14. Bukulmez 0, Deren O. Perinatal outcome in adolescent pregnancies: a case-control study from a Turkish university hospital. Eur J Obstet Gynecol Reprod Biol. 2000; 88(2): 207-12.

15. Ukil D, Esen UI. Early teenage pregnancy outcome: a comparison between a standard and a dedicated teenage antenatal clinic. J Obstet Gynecol. 2002; 22(3): 270-2.

16. Beliz n JM, Althabe F, Cafferata MAL. Health Consequences of the Increasing Caesarean Section Rates. Epidemiol. 2007; 18(4): 485-6.

17. Sachs BP, Kobelin C, Castro MA, Frigoletto F. The risks of lowering the cesarean-delivery rate. N Engl J Med. 1999; 7; 340(1): 54-7.

18. Betrán AP, Merialdi M, Lauer JA, Bing-Shun W, Thomas J, Van Look P, et al. Rates of caesarean section: analysis of global, regional and national estimates. Paediatr Perinat Epidemiol. 2007; 21(2): 98-113.

19. Gibbons L, Belizan JM, Lauer JA, Betrán AP, Merialdi M, Althabe F. The Global Numbers and Costs of Additionally Needed and Unnecessary Caesarean Sections Performed per Year: Overuse as a Barrier to Universal Coverage. World Health Report Background Paper. 2010.

20. Lumbiganon P, Laopaiboon M, Gülmezoglu AM, Souza J-P, Taneepanichskul S, Ruyan P, et al. Method of delivery and pregnancy outcomes in Asia: the WHO global survey on maternal and perinatal health 2007-08. Lancet. Elsevier Ltd; 2010 6; 375(9713): 490-9.

21. Averting Maternal Death and Disability Working Group on Indicators. Averting maternal death and disability. Program note. Using UN process indicators to assess needs in emergency obstetric services: Pakistan, Peru and Vietnam. Int J Gynecol Obstet. 2002; 78(3): 275-82.

22. Gama SG, Viellas EF, Schilithz AO, et al. Factors associated with caesarean section among primiparous adolescents in Brazil, 2011-2012. Cad Saude Publica. 2014; 30 Suppl 1: S1-11.

23. deVinne CM, Creveuil C, Dreyfus M. Does young maternal age increase the risk of adverse obstetric, fetal and neonatal outcomes: A cohort study. Eur J ObstetGynecol Reprod Biol. 2009; 10: 1-6. 